\title{
PERSEPSI PETANI SAYURAN KUBIS, PETSAI DAN WORTEL TERHADAP PESTISIDA ORGANIK DI KELURAHAN KAKASKASEN III KECAMATAN TOMOHON UTARA KOTA TOMOHON
}

\author{
Yemi Nagapa \\ Grace Adonia Josephine Rumagit \\ Caroline Besty Diana Pakasi
}

Naskah diterima melalui Website Jurnal Ilmiah agrisosioekonomi@unsrat.ac.id

: Senin, 12 Juli 2019

Disetujui diterbitkan

: Kamis, 25 Juli 2019

\begin{abstract}
This study aims to determine the perceptions of farmers of cabbage, Chinese cabbage and carrots on the use of organic pesticides in the Village of Kakaskasen III, North Tomohon Sub-district, Tomohon City. The method used in this study is the survey method. Selection of respondents was purposevely. This study used primary data and secondary data. Primary data was collected by interviewing directly with 39 farmers based on a questionnaire that had been prepared previously. Secondary data was obtained from the Village Office of Kakaskasen III, Tomohon Utara Sub-district, local bookstore, and internet through google scholar to get electronic books, journal articles and theses related to the topic of research on vegetable farmers' perceptions of organic pesticides. The data analysis used in this study was descriptive analysis method and used likert scale analysis. The results showed that the total score of perceptions of farmers of cabbage, cabbage and carrot vegetables on organic pesticides in the Village of Kakaskasen III, amounted to 1,153, were in the category of hesitant perceptions with a percentage value of $59.1 \%$ so included in the poor category. ${ }^{*}$ eprm*
\end{abstract}

Keywords: perception, vegetable farmers, organic pesticides, Tomohon

\begin{abstract}
ABSTRAK
Penelitian ini bertujuan untuk mengetahui bagaimana persepsi petani sayuran kubis, petsai dan wortel terhadap penggunaan pestisida organik di Kelurahan Kakaskasen III, Kecamatan Tomohon Utara Kota Tomohon. Metode yang digunakan dalam penelitian ini adalah metode survei. Penelitian ini menggunakan data primer dan data sekunder. Pemilihan responden dilakukan secara sengaja. Data primer di kumpulkan dengan mewawancarai langsung dengan 39 petani berdasarkan daftar pertanyaan (kuesioner) yang sudah disusun sebelumnya. Data sekunder diperoleh dari Kantor Kelurahan Kakaskasen III Kecamatan Tomohon Utara, toko buku lokal, internet melalui google scholar untuk mendapatkan buku elektronik, artikel jurnal dan skripsi yang berkaitan dengan topik penelitian tentang persepsi petani sayuran terhadap pestisida organik. Metode analisis yang digunakan dalam penelitian ini adalah metode analisis deskriptif dan menggunakan analisis skala likert. Hasil Penelitian menunjukkan bahwa total skor tingkat persepsi petani sayuran kubis, petsai dan wortel terhadap pestisida organik di Kelurahan Kakaskasen III, berjumlah 1.153, berada pada kategori tingkat persepsi ragu-ragu dengan nilai persentase sebesar $59,1 \%$ sehingga temasuk pada kategori kurang baik. ${ }^{* e p r m *}$
\end{abstract}

Kata kunci : persepsi, petani sayuran, pestisida organik, Tomohon

Agrisosioekonomi:

Jurnal Transdisiplin Pertanian (Budidaya Tanaman, Perkebunan, Kehutanan, Peternakan, Perikanan), Sosial dan Ekonomi 331 


\section{PENDAHULUAN}

\section{Latar Belakang}

Pertanian merupakan bagian yang tidak terpisahkan dari kehidupan manusia dimana bahanbahan pangan menjadi kebutuhan pokok setiap hari. Pertanian menjadi multi fungsi dimana pertanian merupakan sumber kehidupan sebagian besar masyarakat Indonesia yang mampu menyediakan keragaman menu pangan hortikultura serta menyerap tenaga kerja, juga menumbang devisa untuk negara. Kesadaran terhadap peran tersebut menyebabkan sebagian besar masyarakat masih tetap memelihara lahan pertanian karena Indonesia merupakan negara yang sebagian besar penduduknya adalah petani. Sehubungan dengan itu, perlu adanya pengendalian lahan, dan lingkungan melalui penggunaan pestisida organik, dalam kaitannya untuk mencegah kerugian lahan dan lingkungan masyarakat serta ekonomi dalam jangka panjang (Bappenas 2013).

Sektor pertanian merupakan sektor yang strategis dan berperan penting dalam perekonomian nasional dan kelangsungan hidup masyarakat, kerja dan penyedia pangan dalam negeri. Perkembangan pertanian ertanian organik yang berperan penting dalam pemenuhan kebutuhan pangan organik di Indonesia dimulai pada awal 1980-an dengan bertambahnya luas lahan $\mathrm{p}$ manusia. Di era serba organik seperti sekarang ini, penggunaan pestisida organik cukup mendukung untuk mengatasi masalah gangguan serangan hama pada tanaman komersial. Pestisida organik pun dapat menjamin keamanan ekosistem karena bahan aktifnya berasal dari tanaman atau tumbuhan, hewan dan bahan organik lainnya yang berkhasiat mengendalikan serangan hama pada tanaman (Hasiduwito, 2007).

Umumnya pertanian organik lebih pada tanaman hortikultura seperti sayuran seperti: kubis, petsai dan wortel untuk memenuhi permintaan pasar yangsangat tinggi (Nazaruddin, 2003). Namun peluang tersebut masih kurang dimanfaatkan, karena petani sayuran cenderung lebih menggunakan pestisida kimiawi, padahal pestisida organik tidak meninggalkan residu yang berbahaya pada tanaman maupun lingkungan terlebih kesehatan manusia. Pestisida organik dapat dibuat dengan mudah menggunakan bahan yang murah dan peralatan yang sederhana. Dengan pestisida organik, hama hanya terusir dari tanaman petani tanpa membunuh, selain itu penggunaan pestisida organik dapat menghindari ketergantungan pada pestisida kimia. Penggunaan pestisida organik harus dilakukan dengan hati-hati dan dengan kesabaran serta ketelitian (Nahar 2010) Banyaknya pestisida organik yang disemprotkan ke tanaman harus disesuaikan dengan volume hama dan waktu penyemprotan secara teratur.
Pestisida organik telah dikembangkan di Kota Tomohon, khususnya di Kelurahan Kakaskasen III, dimana sebagian petaninya sudah menggunakan pestisida organik dalam proses bertaninya untuk meningkatkan peningkatan kualitas dan kuantitas dalam menghasilkan sayuran yang bermutu tinggi. Serta adanya kesadaran bahwa penggunaan pestisida kimia merupakan bahan beracun yang sangat berbahaya bagi kesehatan dan lingkungan. Pestisida kimia bersifat polutan sehingga dapat menyebarkan radikal bebas yang mengakibatkan kerusakan bagi tubuh, mutasi gen dan gangguan susunan saraf pusat (Soenandar dan Tjachjono, 2012). Untuk memenuhi kebutuhan dan permintaan konsumen maka sistem pertanian terus mengalami perubahan mengikuti pertambahan jumlah penduduk, peluang dan aspirasi baru.

Persepsi merupakan konsep yang sangat penting dalam psikologi, melalui persepsilah manusia memandang dunianya, apakah dunia terlihat "berwarna" cerah pucat, atau hitam semuanya adalah persepsi manusia yang bersangkutan, persepsi proses seseorang menjadi sadar akan segala sesuatu dalam lingkungannnya melalui indera. Persepsi yang terbentuk dalam diri petani akan mempengaruhi cara pandangnya terhadap manfaat dankeunggulan penggunaan pestisida organik menjadi salah satu faktor penghambat atau pendorong bagi petani sayuran kubis wortel dan petsai terhadap penggunaan pestisida organik di Kelurahan Kakaskasen III merupakan daerah bagian dari Tomohon Utara yang sangat potensial untuk pengembangan komoditas sayuran kubis, petsai dan wortel untuk itu perludikaji tentang persepsi petani sayuran.

\section{Rumusan Masalah}

Berdasarkan latar belakang, maka yang menjadi permasalahan dalam penelitian ini adalah Bagaimana Persepsi petani sayuran kubis, petsai dan wortel terhadap penggunaan pestisida organik di Kelurahan Kakaskasen III Kecamatan Tomohon Utara Kota Tomohon.

\section{Tujuan Penelitian}

Sesuai dengan masalah yang dirumuskan, maka penelitian ini bertujuan untuk mengetahui bagaimana persepsi petani sayuran kubis, petsai dan wortel terhadap penggunaan pestisida organik di Kelurahan Kakaskasen III, Kecamatan Tomohon Utara Kota Tomohon. 


\section{Manfaat Penelitian}

Manfaat Penelitian ini diharapkan menjadi bahan informasi dan pertimbangan bagi pemerintah dalam memberikan penyuluhan kepada petani agar dapat menggunakan pestisida organik yang baik.Bagi petani juga perlu dapat menggunakan pestisida organik yang baik supaya dapat mempertahankan kelestarian alam dan kesehatan lingkungan, serta sebagai sarana mengembangkan pola pikir menambah pengalaman bagi peneliti.

\section{METODE PENELITIAN}

\section{Tempat dan Waktu Penelitian}

Penelitian ini dilakukan di Kelurahan Kakaskasen III, Kecamatan Tomohon Utara Kota Tomohon. Penelitian berlangsung selama tiga bulan mulai dari bulan November 2018 sampai bulan Januari 2019.

\section{Metode Pengumpulan Data}

Metode yang digunakan dalam penelitian ini jenis metode (survei). Penelitian ini menggunakan data primer dan data sekunder. Data primer di peroleh melalui wawancara langsung dengan petani berdasarkan daftar pertanyaan (kuesioner) dan data sekunder diperoleh dari format laporan profil Kelurahan diperoleh dari Kantor Kelurahan Kakaskasen III, Kecamatan Tomohon Utara.

\section{Teknik Pengambilan Sampel}

Metode pengambilan sampel menggunakan metode Purposive sampling yaitu suatu metode dimana sampel yang terpilih dari populasi penelitian adalah petani sayuran yang benar-benar mengunakan pestisida organik. Adapun untuk menentukan jumlah sampel yang diambil dalam penelitian tersebut ini dengan menggunakan rumus perhitungan Slovin (Anonim, 2012), yatu sebagai berikut:

$$
n=\frac{\mathrm{N}}{1+N e^{2}}
$$

Dengan nilai :

$\mathrm{n}=$ Jumlah sampel

$\mathrm{N}=$ Jumlah populasi sebanyak 850 orang

$\mathrm{e}=$ Diinterpresentasikan kesalahan atau

ketidak telitian yang diambil sekitar $15 \%$
Berdasarkan dari data Pemerintah Kelurahan Kakaskasen III, maka diketahui populasi petani sayuran kubis, petsai dan wortel di Kakaskasen III berjumlah 850 orang. Dari jumlah populasi yang ada, maka ditentukan 39 orang untuk menjadi responden.

\section{Konsep Pengukuran Variabel}

Adapun yang menjadi konsep pengukuran variabel dalam penelitian ini adalah beberapa ciri petani yang meliputi :

1. Karakteristik Responden
a. Umur responden
b. Pendidikan Responden terakhir ditempuh SD/ SMP/ SMA dan Perguruan tinggi.
c. Pendidikan informal: Kursus atau pelatihan.
d. Jumlah tanggungan anggota keluarga.
e. Luas lahan: Hampiran areal (Ha)

2. Persepsi Petani Sayuran Kubis, Petsai dan Wortel terhadap pestisida organikdi Kelurahan Kakaskasen III yaitu penilaian dan pertanyaan responden tentang pestisida organik yang meliputi :
a. Persepsi Petani Sayuran terhadap

Kesesuaian. Indikator Pengukurannya

1. Kecocokan dengan kondisi lingkungan Kakaskasen III.

2. Penggunaan Pestisida Organik Sebagai Tradisi oleh Petani sayuran Kubis, Petsai dan Wortel

b. Persepsi Petani Sayuran terhadap Kemudahan untuk dicoba, dengan indikator pengukuran sebagai berikut:

1. Persepsi Petani Sayuran Tingkat Kemampuan pestisida organik untuk dapat dicoba di setiap jenis tanaman sayuran.

2. Persepsi Petani Sayuran Tingkat Perbandingkan Kepraktisan Terhadap Penggunaan Pestisida Organik Dan Pestisida Kimia

c. Persepsi Petani Sayuran tingkat Kerumitan, sebagai indikator pengukuran.

1. Penggunaan Pestisida Organik.

2. Pembuatan Pestisida Organik

d. Persepsi Petani Sayuran terhadap Keuntungan Relatif, indikator pengukuran.

1. Peningkatan produktivitas petani di usahatani.

2. Peningkatan pendapatan atau keuntungan petani di usahatani 
e. Persepsi Petani Sayuran terhadap Kemudahan dilihat hasil. Indikator Pengukuran

1. Kemudahan Tingkat harga hasil panen yang menggunakan pestisida organik.

2. Kemudahan dalam mencari pasar tertentu yang membeli produk sayuran yang menggunakan pestisida organik.

\section{Metode Analisis Data}

Metode Analisis data yang digunakan dalam penelitian ini adalah menggunakan analisis deskriptif, yaitu memberikan gambaran informasi dan mendeskripsikan peristiwa atau kejadian perilaku orang atau keadaan pada tempat tertentu dan akan diinterprentasikan dengan menggunakan Analisis “'Skala Likert”' (Azwar (2010).

Pertanyaan untuk mengukur persepsi petani pestisida organik di Kelurahan Kakaskasen III, Kecamatan Tomohon Utara yaitu, total sebanyak 10 pertanyaan denagan total responden 39 sampel, setiap jawaban dihubungkan dengan bentuk pertanyaan atau dukungan sikap yang diungkapkan dengan kata-kata berikut (Riduwan, 2008 ) :

$\begin{array}{llll}\text { SS : } & \text { Sangat Setuju } & & \\ \text { S : } & \text { Setuju } & & \\ \text { RR : Ragu-ragu } & & \\ \text { TS : } & \text { Tidak Setuju } & & \\ \text { STS : } & \text { Sangat Tidak Setuju } & \\ \text { Bila : } & & & \\ \text { SS diberi skor: } & 5= & 195 \\ \text { S diberi skor: } & 4= & 156 \\ \text { RR diberi skor: } & 3= & 117 \\ \text { TS diberi skor: } & 2= & 78 & \\ \text { STS diberi skor } & : & 1= & 39\end{array}$

Dengan metode perhitungan skor masing-masing pertanyaan :

Jumlah Skor Tiap Kriteria = Capaian Skor $\mathrm{X}$ Jumlah Responden

SS $\quad 5=5 \times 39=195=$ Sangat Setuju

S $\quad 4=4 \times 39=156=$ Setuju

RR $3=3 \times 39=117=$ Ragu-ragu

TS $2=2 \times 39=78=$ Tidak setuju

STS $1=1 \times 39=39=$ Sangat tidak setuju

Jumlah skor ideal untuk setiap item pertanyaan skor tertinggi $=195$ (sangat setuju)

Jumlah skor terrendah $=39$ (sangat tidak setuju)

Dengan interpretasi nilai :

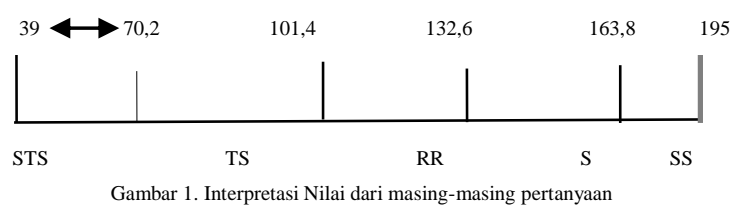

Cara perhitungan skor keseluruhan untuk mengetahui tingkat persepsi petani terhadap pestisida organik.

Jumlah Skor Seluruh Kriterium = Capaian Jumlah Skor X Jumlah Responden X Instrumen Pertanyaan

Untuk :

$$
\begin{array}{ll}
\text { SS } & 5=5 \times 39 \times 10=1950 \\
\text { S } & 4=4 \times 39 \times 10=1560 \\
\text { RR } & 3=3 \times 39 \times 10=1170 \\
\text { TS } & 2=2 \times 39 \times 10=780 \\
\text { STS } & 1=1 X 39 \times 10=390
\end{array}
$$

Jumlah skor ideal untuk keseluruhan pertanyaan $=$ 1950 adalah (sangat setuju)

Jumlah skor rendah $=390$ (sangat tidak setuju). Dengan interpretasi nilai :

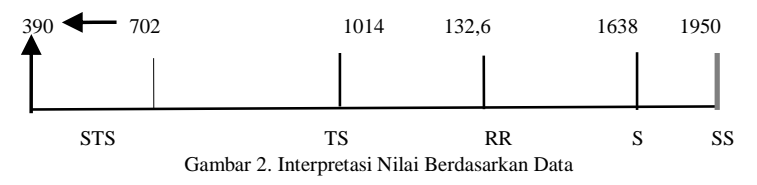

Analisis data yang digunakan merupakan analisis deskriptif yang di analisis dengan menggunakan skala Likert Scale. Adalah sebagai berikut :

$$
\text { Tingkat persepsi Petani }=\frac{\text { Jumlah Skor Hasil Pengumpulan Data }}{\text { Jumlah skor ideal (tertinggi) }} \times 100 \%
$$

Dengan Interpretasi Nilai :

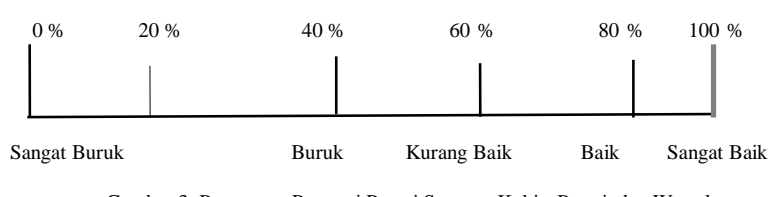

Gambar 3. Persentase Persepsi Petani Sayuran Kubis, Petsai, dan Wortel

Keterangan : Kriteria interpretasi skor persepsi petani Angka $0 \%-20 \%=$ Sangat Tidak Baik Angka $21 \%-40 \%=$ Buruk Angka $41 \%-60 \%=$ Kurang Baik Angka $61 \%-80 \%=$ Baik Angka $81 \%-100 \%=$ Sangat Baik

\section{HASIL DAN PEMBAHASAN}

\section{Deskripsi Wilayah Penelitian}

\section{Keadaan Geografis}

Kelurahan Kakaskasen III terletak pada Kecamatan Tomohon Utara dengan luas wilayah 350 $\mathrm{ha} / \mathrm{m}^{2}$.Dengan Batas-batas wilayah Kelurahan Kakaskasen III adalah sebagai berikut. Sebelah Utara : Kelurahan Kakaskasen II Sebelah Timur : KelurahanKakaskasen Sebelah Selatan : Kelurahan Wailan Sebelah Barat : Kelurahan Gunung Mahawu 


\section{Kondisi Keadaan Demografi atau Penduduk}

Data Penduduk Kelurahan Kakaskasen III pada tahun 2018 memiliki jumlah Penduduk sebanyak 4872 jiwa terdiri dari Laki-laki 2522 jiwa sedangkan perempuan terdiri dari 2350 jiwa dengan dapat dijelaskan pada Tabel 1.

Tabel 1. Jumlah Penduduk Menurut Jenis Kelamin

\begin{tabular}{llcc}
\hline No. & Jenis Kelamin & Jumah (Jiwa) & Persentase (\%) \\
\hline 1 & Laki-laki & 2522 & 51,7 \\
2 & Perepuan & 2350 & 48,2 \\
\hline & Jumlah & 4872 & 100 \\
\hline
\end{tabular}

Tabel 1 menunjukkan bahwa jumlah jenis kelamin laki-laki, $(51,7 \%)$ sedangkan jumlah perempuan terdapa $(48,2 \%)$ jiwa, di Kelurahan Kakaskasen III, lebih mendominasi adalah jumlah penduduk laki-laki Jumlah keseluruhan penduduk terdapat sebanyak 4872 jiwa. Kelurahan Kakaskasen III terdiri atas beberapa etnis yang hidup bersama-sama yaitu Minahasa, Makasar dan Madura.

\section{Tingkat Pendidikan Penduduk}

Pembangunan tingkat pendidikan menjadi salah satu program prioritas baik pemerintah desa, maupun masyarakat secara umum, karena sektor ini akan menjadipenentu kualitas Sumber Daya Manusia (SDM) yang terdapat di Kelurahan Kakaskasen III. Tahun 2018, dapat dilihat pada Tabel 2.

Tabel 2. Jumlah Penduduk Tingkat Pendidikandi Kelurahan Kakaskasen III

\begin{tabular}{lcc}
\hline $\begin{array}{c}\text { Tingkat Pendidikan } \\
\text { Penduduk }\end{array}$ & $\begin{array}{c}\text { Jumlah Penduduk } \\
\text { (Jiwa) }\end{array}$ & $\begin{array}{c}\text { Persentase } \\
(\%)\end{array}$ \\
\hline SD & 304 & 35,7 \\
SMP & 270 & 31,7 \\
SMA/SMK & 211 & 24,8 \\
S-1 & 101 & 11,8 \\
S-2 & 13 & 1,5 \\
\hline Jumlah & 899 & 100 \\
\hline
\end{tabular}

Tabel 2 menunjukkan bahwa jumlah penduduk menurut tingkat pendidikan di Kelurahan Kakaskasen III, adalah pendidikan Sekolah Dasar (SD) dengan jumlah penduduk sebesar 304 jiwa persentase $35,7 \%$, melalui data diatas dapat dikatakan wajib belajar di Kelurahan Kakaskasen III, supaya berjalan dengan baik dan cukup berhasil.Data diatas belum termasuk penduduk yang belum berusia sekolah.

\section{Jumlah Penduduk Menurut Mata Pencaharian}

Adapun jenis mata pencaharian pokok dari penduduk di Kelurahan Kakaskasen III, menurut Pekerjaan penduduk dapat di lihat pada Tabel 3.

\begin{tabular}{|c|c|c|c|}
\hline Jenis Pekerjaan & $\begin{array}{l}\text { Jenis Kelamin } \\
\text { Laki-Laki }\end{array}$ & $\begin{array}{c}\text { Jenis Kelamin } \\
\text { Perempuan } \\
\end{array}$ & Total \\
\hline Petani & 503 & 59 & 562 \\
\hline Buruh Tani & 10 & - & 10 \\
\hline PNS & 84 & 109 & 193 \\
\hline Karyawan Perusahan Swasta & 40 & 33 & 73 \\
\hline Dokter Swasta & 4 & 2 & 6 \\
\hline TNI & 2 & 2 & 4 \\
\hline POLRI & 7 & - & 7 \\
\hline Dosen Swasta & 4 & 3 & 7 \\
\hline Guru Swasta & 7 & 3 & 10 \\
\hline Seniman/Artis & 2 & 1 & 3 \\
\hline $\begin{array}{l}\text { Pengusaha, kecil, dan } \\
\text { menengah }\end{array}$ & 2 & 2 & 4 \\
\hline $\begin{array}{l}\text { Pensiunan PNS, TNI, dan } \\
\text { POLRI }\end{array}$ & 30 & 18 & 48 \\
\hline Jumlah & 695 & 232 & 952 \\
\hline
\end{tabular}

Tabel 3 menunjukkan bahwa besar jenis pekerjaan Masyarakat Kelurahan Kakaskasen III, adalah tertinggi sebagai petani yaitu jumlah sebanyak 562 jiwa. Hal ini di sebabkan kondiri wilayah Kakaskasen III tersebut sangat baik untuk sumber daya alam segi sektor pertanian, sehingga rata-rata mayoritas penduduk bekerja sebagai petani. Selain jenis pekerjaan diatas, ada juga jenis pekerjaan lain pekerjaan sampingan bagi beberapa penduduk, yaitu sebagai sopir angkutan dan tukang ojek.

\section{Karakteristik Responden}

\section{Tingkat Umur Responden}

Umur dapat mempengaruhi kemampuan seseorang untuk bekerja secara fisik serta dapat menentukan persepsi seseorangcara berpikir. Secara umum, umur juga dapat mempengaruhi produktivitas dalam kerja dan peranan dalam proses pengambilan keputusan, berbagai pekerjaan yang dilakukannya semakin berkurangUmur produktif berada antar 18 tahun hingga 65 tahun yang bekerja. Karena pada dasarnya petani yang berumur muda lebih kuat bekerja dan petani yang umur lebih tua, dalam produktif fisik lemah. Komposisi umur responden dalam penelitian ini disajikan pada umur petani responden dapat dilihan pada Tabel 4.

Tabel 4. Jumlah Responden dan Persentase Menurut Umur

\begin{tabular}{cccc}
\hline No & Umur (Tahun) & Jumlah Responden (Orang) & Persentase (\%) \\
\hline 1 & $18-35$ & 9 & 23 \\
2 & $36-45$ & 11 & 28,2 \\
3 & $46-55$ & 13 & 33,3 \\
4 & $56-65$ & 6 & 15,3 \\
\hline Jumlah & 39 & 100 \\
\hline \multicolumn{5}{l}{ Sumber : Data Diolah Dari Data Primer, 2018 }
\end{tabular}

Tabel 4 menunjukkan bahwa besar dari responden berusia berada pada umur 46-55 tahun, yaitu sebanyak 13 orang atau $(33,3 \%)$ sebagian dari total responden kemudian kembali pada interval umur 36-45 tahun dengan jumlah 11 orang atau $(28,2 \%)$ Selanjutnya umur pada 18-35 tahun yaitu 9 orang atau $(23 \%)$, yang sedikit umur 6 orang atau $(15,3 \%)$. Menurut peneliti umur responden yang tertua berumur 56 tahun keatas dan yang umur termuda 35 tahun kebawah. 


\section{Jumlah Responden Menurut Tingkat Pendidikan}

Perkembangan suatu usaha dalam bidang apapun haruslah ditunjang faktor pendidikan formal maupun non formal. Pendidikan sangat berperan penting dalam menciptakan perubahan-perubahan sikap serta kemampuan berpikir dan bertindak dalam kehidupan masyarakat maupun pengembangan pribadi. Peningkatan kualitas pendidikan yang memiliki intelektual dapat memberikan pemahaman baik dan buruk hasil penelitiandi Kerulahan Kakaskasen III, tingkat pendidikanpetani responden dapat dilihat pada Tabel 5 .

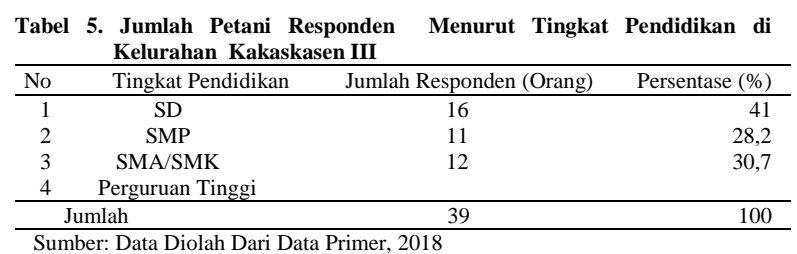

Tabel 5 menunjukkan bahwa tingkat pendidikan responden jumlah pendidikan SD, terbanyak 16 petani atau (41,\%), hal ini menunjukkan masih rendahnya pendidikan petani sayuran kubis, petsai dan wortel di Kelurahan Kakaskasen III. Rendahnya tingkat pendidikan masih dapat diatasi dengan tingginya produktifitas dari segi umur, karena umur responden masih dapat mudah menyesuaikan atau memperajari teknik atau didunia pekerjaan.

\section{Jumlah Responden Menurut Tingkat Pendidikan Informal : Kursus Atau Pelatihan}

Menurut petani di usahatani sayuran di Kelurahan Kakaskasen III, adalah tidak pernah mengikuti kegiatan-kegiatan, kursus seperti penyuluhan, pelatihan, untuk meningkatkan pengetahuan dan keterampilan petani secara nyata, dalam membuat dan mengaplikasikan pestisida organik.

\section{Jumlah Tanggungan Keluarga Responden}

Jumlah tanggungan keluarga sebagai unit masyarakat terkecil biasanya terdiri dari ayah, Ibu dan anak serta anggota keluarga lain yang menjadi tanggungan petani Jumlah anggota keluarga sangatlah berpengaruh pada jumlah tanggungan petani dan distribusi pendapatan hasil usahatani.Jumlah petani responden berdasarkan tanggungan keluarga dapat dilihat pada Tabel 6 .

\begin{tabular}{|c|c|c|c|}
\hline No & $\begin{array}{c}\text { Jumlah Tanggungan } \\
\text { Keluarga (Orang) }\end{array}$ & $\begin{array}{l}\text { Jumlah Responden } \\
\text { (Orang) }\end{array}$ & Persentase (\%) \\
\hline 1 & 2 & 5 & 12,8 \\
\hline 2 & 3 & 11 & 28,2 \\
\hline 3 & 4 & 17 & 7,6 \\
\hline 4 & 5 & 6 & 15,3 \\
\hline \multicolumn{2}{|r|}{ Jumlah } & 39 & 100 \\
\hline
\end{tabular}

Tabel 6 menunjukkan bahwa mayoritas jumlah tanggungan keluarga terbanyak 4 keluarga persentase $(43,5 \%)$, yaitu berjumlah 17 responden, dan tanggungan rendah pada 2 tanggunagan atau $(12,8 \%)$. Hal ini dapat dilihat jumlah tanggungan pada petani sayuran kubis, petsai dan wortel di Kelurahan Kakaskasen III cukup rendah, biaya kebutuhan rumah tangga masih dapat diatasi.

\section{Luas Lahan Pemilikan Responden}

Luas lahan sangat mempengaruhi besar kecilnya tingkat produksi sayuran kubis, petsai dan wortel adalah Semakin luas lahan maka hasil yang diproduksi semakin tinggi.Begitu sebaliknya jika luas lahan sempit maka hasil diperoleh semakin sedikit.Luas lahan yang diusahakan masing-masing petani bervariasi antara 1 (Ha). Jumlah petani responden menurut luas lahan dapat dilihat pada Tabel 7.

Tabel 7. Jumlah dan Persentase Responden Menurut Luas Lahan.

\begin{tabular}{cccc}
\hline No & $\begin{array}{c}\text { Luas Lahan } \\
(\text { Ha) }\end{array}$ & $\begin{array}{c}\text { Jumlah Responden } \\
\text { (Orang) }\end{array}$ & $\begin{array}{c}\text { Persentase } \\
(\%)\end{array}$ \\
\hline 1 & 0,5 & 10 & 25,6 \\
2 & 1 & 16 & 41 \\
3 & $0,5-1$ & 3 & 7,6 \\
4 & 2 & 10 & 25,6 \\
\hline Jumlah & \multicolumn{3}{l}{}
\end{tabular}

Tabel 7 menunjukkan bahwa luas lahan yang paling banyak rata-rata masing-masingdiolah petani responden yaitu 1 (ha) masing-masing sebanyak 16 responden atau $(41, \%$, petani yang mengelola dengan pemilikan luas lahan (ha) untuk pertanian tanaman sayuran kubis, petsai dan wortel di Kelurahan Kakaskasen III Sedangkan yang memiliki luas lahan petani antara 0,5- 1 (ha), sekitar seperempat dari jumlah petani dengan menguasai sepertiga lahan 3 atau $(7,6 \%)$, adalah skala menengah dengan pada luas lahan, 0,5- 1 atau luas lahan (ha) sayuran.

\section{Persepsi Petani Sayuran Kubis, Petsai dan Wortel Terhadap Pestisida Organik di Kelurahan Kakaskasen III}

\section{Persepsi Petani Sayuran terhadap Tingkat Kesesuaian}

Persepsi petani sayuran mengenai tingkat kesesuaian terhadap penggunaan pestisida organik ada dua indikator, kecocokan dengan kondisi lingkungan dan keadaan tempat tinggal petani penggunaan pestisida organik, sebagai tradisi oleh Petani sayuran Kubis, Petsai dan Wortel dimana dalam penelitian ini di Kelurahan Kakaskasen III yang merupakan petani di usahatani menjadi tuntutan bagi petani agar tetap menjalankan petani di usahataninya melihat kecocokannya dengan kondisi lingkungan khususnya di Kelurahan Kakaskasen III. 
Tabel 8. Persepsi Petani Sayuran Tingkat Kecocokan dengan Kondisi Lingkung

\begin{tabular}{lcccc}
\multicolumn{6}{c}{ terhadap Penggunaan Pestisida Organik } & & \\
\hline $\begin{array}{c}\text { Alternatif } \\
\text { Jawaban }\end{array}$ & $\begin{array}{c}\text { Alternatif } \\
\text { Skor }\end{array}$ & $\begin{array}{c}\text { Jumlah Responden } \\
\text { (Orang) }\end{array}$ & $\begin{array}{c}\text { Persentase } \\
\text { Responden }(\%)\end{array}$ & $\begin{array}{c}\text { Total } \\
\text { Skor }\end{array}$ \\
\hline Sangat Setuju & 5 & 6 & 15,3 & 30 \\
Setuju & 4 & 19 & 48,7 & 76 \\
Ragu-Ragu & 3 & 9 & 23 & 27 \\
Tidak Setuju & 2 & 4 & 10,2 & 8 \\
Sangat Tidak & 1 & 1 & 2,5 & 1 \\
Setuju & & & & \\
\hline \multicolumn{1}{c}{ Total } & 39 & 100 & 142 \\
\hline
\end{tabular}

Tabel 8 menunjukkan bahwa responden yang paling banyak mengenai kecocokannya adalah menjawab (setuju) yaitu sebanyak 19 orang $(48,7 \%)$ dan yang menjawab (Ragu-ragu) sebanyak 9 orang $(23 \%)$ serta yang berpendapat (sangat setuju) 6 orang $(15,3 \%)$ dan yang menjawab (tidak setuju), sebanyak 4 orang $(10,2 \%)$ dan responden menganggap (sangat tidak setuju) 1 orang $(2,5 \%)$. Dengan total skor yang diperoleh 142 dan interpretasi sebanyak 72,8\%. Maka nilainya tergolong baik. Persepsi tentang kecocokan yang disampaikan petani sayuran menujukkan bahwa cocok dengan lingkungan Kelurahan Kakskasen III.

Tabel 9. Persepsi petani sayuran Kubis, Petsai dan Wortel mengenai tingkat

\begin{tabular}{lcccc}
\multicolumn{6}{c}{ Tradisi terhadap Penggunaan Pestisida Organik } \\
$\begin{array}{l}\text { Alternatif } \\
\text { Jawaban }\end{array}$ & $\begin{array}{c}\text { Alternatif } \\
\text { Skor }\end{array}$ & $\begin{array}{c}\text { Jumlah Responden } \\
\text { (Orang) }\end{array}$ & $\begin{array}{c}\text { Persentase } \\
\text { Responden }(\%)\end{array}$ & Total Skor \\
\hline Sangat Setuju & 5 & 3 & 7,6 & 15 \\
Setuju & 4 & 20 & 51,2 & 80 \\
Ragu-Ragu & 3 & 8 & 20,5 & 24 \\
Tidak Setuju & 2 & 8 & 20,5 & 16 \\
Sangat Tidak Setuju & 1 & - & - & - \\
\hline \multicolumn{5}{r}{ Total } \\
\hline \multicolumn{5}{l}{ Sumber: Diolah Dari Data Primer, 2018 } \\
\hline
\end{tabular}

Tabel 9 menunjukkan bahwa jumlah responden yang paling banyak menjawab mengenai penggunaannya berdarkan adat dan kebiasaan petani sayuran adalah (setuju) yaitu sebanyak 20 orang $(51,2 \%)$ dan yang menjawab (Tidak setujuh dan Raguragu) sebanyak 8 orang $(20,5 \%)$ dan responden menganggap (sangat setuju) sebanyak 3 orang $(7,6 \%)$. Total skor yang diperoleh adalah 135 dan interpretasi sebesar 69,2\%. Dan termasuk kategori baik.

Tabel 10. Rekapitulasi Total Skor, Persepsi Petani Sayuran Kubis, Petsa Dan Wortel dan Interpretasi terhadap Kesesuaian

\begin{tabular}{|c|c|c|c|c|}
\hline No & Pertanyaan & Total Skor & $\begin{array}{c}\text { Indeks } \\
\text { Persepsi (\%) }\end{array}$ & $\begin{array}{l}\text { Inter } \\
\text { pretasi }\end{array}$ \\
\hline 1 & $\begin{array}{lr}\text { Persepsi Petani } & \text { Sayuran } \\
\text { tingkat Kecocokan dengan } \\
\text { kondisi } & \text { lingkungan } \\
\text { terhadap } & \text { penggunaan } \\
\text { Pestisida Organik }\end{array}$ & 142 & 72,8 & Setuju \\
\hline 2 & $\begin{array}{l}\text { Persepsi petani } r \text { sayuran } \\
\text { kubis petsai dan } \\
\text { mengenai tingkat } \\
\text { terhadap Tradisi } \\
\text { Pestisida Organik } \\
\end{array}$ & 135 & 69,2 & Setuju \\
\hline & Total & 277 & 71 & Setuju \\
\hline
\end{tabular}

Sumber : Data Diolah Dari Data Primer 2018

Tabel 10 menunjukkan bahwa dari keseluruhan indikator tingkat Persepsi Petani Sayuran Kubis, Petsai Dan Wortel terhadap Kesesuaian terletak pada skor 277 dan persentase tingkat persepsi petani sayuran sebesar $72,8 \%$.
Artinya responden berpendapat (Baik) terhadap penggunaan Pestisida Organik. Dan indikator yang memperoleh persentasi Persepsi petani sayuran kubis, petsai dan wortel mengenai tingkat Tradisi terhadap Penggunaan Pestisida Organik yaitu sebesar 69, $2 \%$. Hal ini menujukkan bahwa responden menggangap tingkat Tradisi Penggunaan Pestisida Organik Baik.

\section{Persepsi Petani Sayuran Terhadap Tingkat Kemudahan Untuk Dicoba Terhadap Pestisida Organik}

Persepsi petani mengenai tingkat kemudahan pestisida organik untuk dicoba mencakup kemudahan untuk menerapkan pestisida organik dalam usahatani sayuran kubis, petsai dan wortel di Kelurahan Kakaskasen III, kemampuan pestisida organik untuk dapat dicoba di setiap jenis tanaman sayuran yang ditanam di Kelurahan Kakaskasen III. Persepsi petani sayuran mengenai tingkat kemudahan untuk menerapkan penggunaan pestisida organik di Kelurahan Kakaskasen III dapat di jelaskan pada Tabel 11.

Tabel 11. Persepsi Petani Sayuran mengenai tingkat Kemudahan untuk coba di set

\begin{tabular}{lcccc}
\multicolumn{5}{c}{ jenis tanaman sayuran yang ditanam di Kelurahan Kakaskasen III } \\
\hline $\begin{array}{l}\text { Alternatif } \\
\text { Jawaban }\end{array}$ & $\begin{array}{c}\text { Alternatif } \\
\text { Skor }\end{array}$ & $\begin{array}{c}\text { Jumlah Responden } \\
\text { (Orang) }\end{array}$ & Persentase (\%) & Total Skor \\
\hline Sangat Setuju & 5 & 1 & 2,5 & 5 \\
Setuju & 4 & 1 & 2,5 & 4 \\
Ragu-Ragu & 3 & 11 & 28,2 & 33 \\
Tidak Setuju & 2 & 21 & 53,8 & 42 \\
Sangat Tidak Setuju & 1 & 5 & 12,8 & 5 \\
\hline Total & 39 & 100 & 89 \\
\hline \multicolumn{5}{l}{ Sumber : Data Di Olah Dari Data Primer 2018 }
\end{tabular}

Tabel 11 menunjukkan bahwa responden yang paling banyak menjawab mengenai kepraktisan penggunaan pestisida organik (tidak setuju) yaitu sebanyak 21 responden $(53,8 \%)$, dan yang masih (Ragu-ragu) 11 orang $(28,2 \%)$ serta yang menjawab (sangat tidak setuju) 5 orang $(12,8 \%)$ dan 1 orang $(2,5)$ responden menganggap (setuju dan sangat setuju). Total skor yang diperoleh adalah 89 dan interpretasi sebesar 45,6\%. Maka itu tergolong kurang baik.

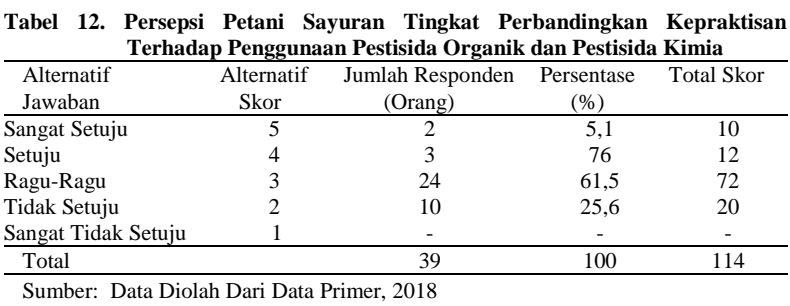

Tabel 12 menunjukkan bahwa responden yang paling banyak adalah yang menjawab (Raguragu) 24 orang $(61,5 \%)$ dan (tidak setuju) sebanyak 10 orang $(25,6)$ serta responden menganggap (setuju) sebanyak 3 orang $(7,6 \%)$ dan menjawab (sangat setuju) 2 orang $(5,1 \%)$. Dengan total skor yang peroleh 114 dan interpretasi sebanyak $58,4 \%$. Dengan ini nilai tergolong kurang baik. 


\begin{tabular}{|c|c|c|c|c|}
\hline Tabel & $\begin{array}{l}\text { Rekapitulasi Total Skor, } \\
\text { Interpretasi terhadap Kemu }\end{array}$ & $\begin{array}{l}\text { ingkat Pers } \\
\text { ahan untuk }\end{array}$ & $\begin{array}{l}\text { psi Petani } \\
\text { licoba }\end{array}$ & Sayuran dan \\
\hline No. & Pertanyaan & Total Skor & $\begin{array}{l}\text { Tingkat } \\
\text { Persepsi \% }\end{array}$ & Intrepretasi \\
\hline 1. & $\begin{array}{l}\text { Petani Petani Sayuran tingkat } \\
\text { Kemudahan untuk coba disetiap } \\
\text { jenis tanamana sayuran yang } \\
\text { tanam di Kelurahan Kakaskasen } \\
\text { III }\end{array}$ & 89 & 45,6 & Buruk \\
\hline 2.. & $\begin{array}{l}\text { Persepsi Petani Sayuran tingkat } \\
\text { Perbandingkan Kepraktisan } \\
\text { terhadap Penggunaan Pestisida } \\
\text { Organik dan Pestisida Kimia }\end{array}$ & 114 & 58,4 & Ragu-Ragu \\
\hline & Total & 203 & 52 & Buruk \\
\hline
\end{tabular}

Tabel 13 menunjukkan bahwa dari seluruh indikator tingkat persepsi petani sayuran terhadap Kemudahan untuk mencoba terhadap Pestisida Organik terletak pada angka 203 dan persentase tingkat persepsi petani sayuran kubis, petsai dan wortel sebanyak 45,6\%. Artinya Persepsi petani sayuran berpendapat (Buruk) terhadap Kemudahan untuk mencoba, Pestisida Organik dan Kimia, indikator yang responden mengaggap sangat rumit pemperoleh persentase adalah 58,4\%. Hal ini menunjukkan bahwa responden menganggap kurang baik.

\section{Persepsi Petani Sayuran Terhadap Kerumitan yang Rendah}

Persepsi petani mengenai tingkat kerumitan terhadap penggunaan dan pembuatan pestisida organik, serta penggunaan pestisida yang praktis dapa memperlihatkan kecenderungan subtitusi pestisida dari kimia ke organik. Petani sayuran kadang rumit untuk penggunaan pestisida organik, maupun pembuatan organik maka persepsilah mengenai, penggunaan pestisida organik dan pembuatan organik.

\begin{tabular}{|c|c|c|c|c|}
\hline $\begin{array}{l}\text { Alternatif } \\
\text { Jawaban }\end{array}$ & $\begin{array}{c}\text { Alternatif } \\
\text { Skor }\end{array}$ & $\begin{array}{c}\text { Jumlah } \\
\text { Responden } \\
\text { (Orang) }\end{array}$ & $\begin{array}{c}\text { Persentase } \\
\text { Responden \% }\end{array}$ & $\begin{array}{c}\text { Total } \\
\text { Skor }\end{array}$ \\
\hline Sangat Setuju & 5 & 2 & 5,1 & 10 \\
\hline Setuju & 4 & 9 & 23 & 36 \\
\hline Ragu-Ragu & 3 & 8 & 20,5 & 24 \\
\hline Tidak Setuju & 2 & 15 & 38,4 & 30 \\
\hline Sangat Tidak Setuju & 1 & 5 & 12,8 & 5 \\
\hline Total & & 39 & 100 & 105 \\
\hline
\end{tabular}

Tabel 14 menunjukkan bahwa responden yang menganggap (tidak setuju) mengenai penggunaan pestisida organik sebanyak 15 orang atau $(38,4 \%)$. Artinya Responden menganggap bahwa dan 9 orang (23\%) dan responden menganggap (setuju) dan juga 8 orang (20,5\%) masih (meragu-ragukan) dan 5 orang (12,8\%) (sangat tidak setuju) karena pembuatan pestisida organik sangat rumit serta 2 orang $(5,1 \%)$ responden mengnggap (sangat setuju). Dengan total skor tingkat kerumitan penggunaan pestisida organik adalah 105 dan interpretasi sebesar 53,8\%. Dan termasuk kategori kurang baik.
Tabel 15. Persepsi Petani Sayuran tingkat Kerumitan terhadap

\begin{tabular}{lcccc}
\multicolumn{5}{c}{ Pembuatan Pestisida Organik } \\
\hline Alternatif & $\begin{array}{c}\text { Alternatif } \\
\text { Skor }\end{array}$ & $\begin{array}{c}\text { Jumlah Responden } \\
\text { (Orang) }\end{array}$ & $\begin{array}{c}\text { Persentase } \\
(\%)\end{array}$ & $\begin{array}{c}\text { Total } \\
\text { Skor }\end{array}$ \\
\hline Sangat Setuju & 5 & 2 & 5,1 & 10 \\
Setuju & 4 & 3 & 76 & 12 \\
Ragu-Ragu & 3 & 24 & 61,5 & 72 \\
Tidak Setuju & 2 & 10 & 25,6 & 20 \\
Sangat Tidak Setuju & 1 & - & - & - \\
\hline Total & \multicolumn{5}{c}{ S } & 39 & 100 & 114 \\
\hline \multicolumn{2}{l}{ Sumber: Data Diolah Dari Data Primer, 2018 }
\end{tabular}

Tabel 15 menunjukkan bahwa responden yang paling banyak adalah yang menjawab (Raguragu) 24 orang $(61,5 \%)$. Artinya responden berpendapat bahwa seimbang karena, tahap pembuatan pestisida organik ini tidak susah dan susah artinya rumit maka masih (Ragu-rag) dan (tidak setuju) sebanyak 10 orang $(25,6 \%)$ serta responden menganggap (setuju) sebanyak 3 orang $(7,6 \%)$ dan menjawab (sangat setuju) 2 orang $(5,1 \%)$. Dengan total skor yang peroleh 114 dan interpretasi sebanyak 58,4\%. Dengan ini nilai tergolong kurang baik.

Tabel 16. Rekapitulasi Total Skor, Persepsi Petani Sayuran dan Interpretasi terhadap Kerumitan yang Rendah

\begin{tabular}{|c|c|c|c|c|}
\hline No & Pertanyaan & $\begin{array}{l}\text { Total } \\
\text { Skor }\end{array}$ & $\begin{array}{l}\text { Indeks } \\
\text { Persepsi (\%) }\end{array}$ & $\begin{array}{l}\text { Inter } \\
\text { pretasi }\end{array}$ \\
\hline 1 & $\begin{array}{lr}\text { Persepsi } & \text { Petani Sayuran } \\
\text { tingkat } & \text { Kerumitan } \\
\text { terhadap } & \text { Penggunaan } \\
\text { Pestisida Organik. }\end{array}$ & 105 & 53,8 & Ragu-lagu \\
\hline 2 & $\begin{array}{lr}\text { Persepsi } & \text { Petani } \\
\text { tingkat } & \text { Kerumitan } \\
\text { terhadap } & \text { Pembuatan } \\
\text { Pestisida } & \text { Organik }\end{array}$ & 114 & 58,4 & Kurang baik \\
\hline & Total & 219 & 56,6 & Kurang baik \\
\hline
\end{tabular}

Tabel 16 menunjukkan bahwa dari seluruh indikator tingkat Kerumitan terhadap penggunaan Pestisida Organik terletak pada angka 219 dan indeks Persepsi 53,8. Artinya Persepsi petanitingkat Kerumitan terhadap penggunaan Pestisida Organik sangat rumit untuk menerapkan ke sayuran kubis, petsai dan wortel dalam indikator tingkat Kerumitan terhadap Pembuatan Pestisida Organik adalah sebesar 58,4 \%. Artinya sangat rumit untuk pembuatan pestisida organik. Dengan ini nilai Interpretasi tergolong kurang baik.

\section{Persepsi Petani Sayuran Kubis, Petsai dan Wortel terhadap Keuntungan Relatif}

Keuntungan relatif suatu inovasi adalah tingkatan dimana suatu ide baru dapat dianggap suatu hal yang lebih baik dari pada ide-ide yang ada sebelumnya, dan secara menguntungkan. Dalam indikator persepsi petani terhadap pestisida organik dari segi peningkatan produktivitas usahatani, peningkatan pendapatan atau keuntungan petani di usahatani dan dua indikator setiap responden berpendapat di tunjukkan pada Tabel 17. 
Tabel 17. Persepsi Petani Sayuran tingkat Peningkatan Produktivitas Hasil \begin{tabular}{llll}
\multicolumn{5}{c}{ Petani terhadap penggunaan Pestisida Organik } & \\
\hline Alternatif & Alternatif Jumlah Responden & Persentase & Total
\end{tabular}

\begin{tabular}{lcccc}
\hline $\begin{array}{c}\text { Alternatif } \\
\text { Jawaban }\end{array}$ & $\begin{array}{c}\text { Alternatif } \\
\text { Skor }\end{array}$ & $\begin{array}{c}\text { Jumlah Responden } \\
\text { (Orang) }\end{array}$ & $\begin{array}{c}\text { Persentase } \\
\text { Responden }(\%)\end{array}$ & $\begin{array}{c}\text { Total } \\
\text { Skor }\end{array}$ \\
\hline Sangat Setuju & 5 & 2 & 5,1 & 10 \\
Setuju & 4 & 11 & 28,2 & 44 \\
Ragu-Ragu & 3 & 7 & 17,9 & 21 \\
Tidak Setuju & 2 & 12 & 30,7 & 24 \\
Sangat Tidak Setuju & 1 & 7 & 17,9 & 7 \\
\hline \multicolumn{2}{r}{ Total } & 39 & 100 & 106 \\
\hline Sol & & & &
\end{tabular}

Sumber: Data Diolah Dari Data Primer, 2018

Tabel 17 menunjukkan bahwa jumlah responden yang paling banyak adalah yang menganggap bahwa (tidak setuju) mengenai Produktivitas hasil sebanyak 12 orang $(30,7 \%)$ dan (setuju) sebanyak 11 orang $(28,2 \%)$ serta yang menganggap (Ragu-ragu) sebanyak 7 orang $(17,9 \%)$ dan 2 responden menjawab bahwa (sangat setuju) sebanyak 2 orang $(5,1 \%)$. Dengan ini total skor yang di peroleh 106 dan di interpretasi sebanyak 54,3\%. Maka nilai persentase dapat dikatan kurang baik.

Tabel 18. Persepsi Petani sayuran tingkat Peningkatan pendapatan atau Keuntungan petani di usahatani terhadap Penggunaan

\begin{tabular}{|c|c|c|c|c|}
\hline $\begin{array}{l}\text { Alternatif } \\
\text { Jawaban }\end{array}$ & $\begin{array}{l}\text { Alternatif } \\
\text { Skor }\end{array}$ & $\begin{array}{cc}\mathrm{f} & \text { Jumlah } \\
\text { Responden (Orang) }\end{array}$ & $\begin{array}{r}\text { Persentase } \\
\text { Responden (\%) }\end{array}$ & $\begin{array}{l}\text { Total } \\
\text { Skor }\end{array}$ \\
\hline Sangat Setuju & 5 & - & - & - \\
\hline Setuju & 4 & 12 & 30,7 & 48 \\
\hline Ragu-Ragu & 3 & 7 & 17,9 & 21 \\
\hline Tidak Setuju & 2 & 14 & 35,8 & 28 \\
\hline Sangat Tidak Setuju & 1 & 6 & 15,3 & 6 \\
\hline Total & & 39 & 100 & 103 \\
\hline
\end{tabular}

Sumber : Data Diolah Dari Data Primer 2018

Tabel 18 menunjukkan bahwa jumlah responden yang menganggap (tidak setuju) mengenai tingkat pendapatan petani terhadap penggunaan pestisida organik sebanyak 14 orang $(35,8 \%)$ dan responden menjawab (setuju) sebanyak 12 orang $(30,7 \%)$ serta 7 orang $(17,9)$ (Ragu-ragu) serta 6 orang $(15,3)$ menganggap (sangat tidak setuju). Dengan total skor yang diperoleh 103 dan interpretasi sebanyak $52,8 \%$. Dan termasuk kategori kurang baik.

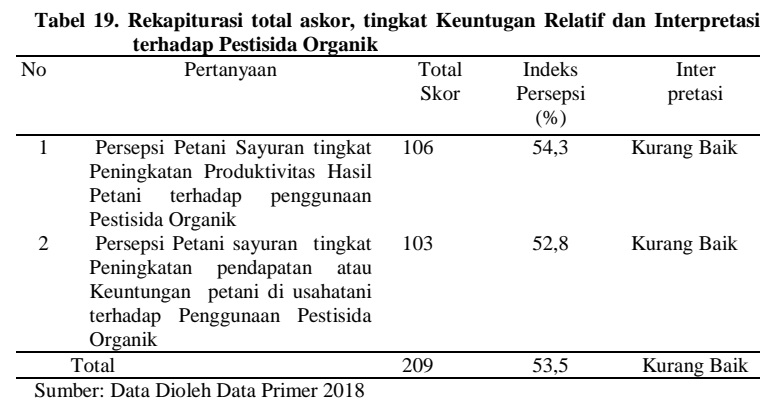

Tabel 19 menunjukkan bahwa dari seluruh indikator dapat menujur pada angka 209 tingkat Peningkatan Produktivitas Hasil Usaha Petani terhadap penggunaan Pestisida Organik adalah sebesar 54,3\%. Artinya kurang produktivitas terhadap penggunaan Pestisida Organik, karenatidak pernah untuk mencapai hasil yang optimal, dan indikator Peningkatan pendapatan atau Keuntungan petani di usahatani terhadap penggunaan pestisida organik, adalah sebesar 52,8\%. Hal ini menujukkan interpretasi nilai Kurang baik, karena yang responden menganggap bahwa, Aktivitasnya dari penggunaan terhadap produk pestisida organik merupakan sumber penghasilan seseorang, sedangkan kenaikan harga produk organik tidak mencapai keingginan.

\section{Persepsi Petani Sayuran Tingkat Kemudahan Dilihat Hasil Petani Di Usahatani Terhadap Penggunaan Pestisida Organik}

Persepsi petani mengenai tingkat kemudahan untuk melihat hasil produk penggunaan pestisida organik, tingkat harga hasil panen yang menggunakan pestisida organik, serta kemudahan dalam mencari pasar tertentu yang membeli produk sayur yang menggunakan pestisida organik di Kelurahan Kakaskasen III. Dalam indikator ini dapat di jelaskan melalui Tabel 20.

\begin{tabular}{lcccc} 
Tabel 20. & $\begin{array}{c}\text { Persepsi Petani Sayuran Kubis, Petsai dan Wortel tingkat } \\
\text { Peningkatan Harga produkterhadap Pestisida Organik }\end{array}$ \\
\hline Alternatif & Alternatif & Jumlah Responden & Persentase & Total \\
Jawaban & Skor & (Orang) & $(\%)$ & Skor \\
\hline Sangat Setuju & 5 & 10 & 25,6 & 50 \\
Setuju & 4 & 20 & 51,2 & 80 \\
Ragu-Ragu & 3 & 6 & 15,3 & 18 \\
Tidak Setuju & 2 & 3 & 7,6 & 6 \\
Sangat Tidak Setuju & 1 & - & - & - \\
\hline \multicolumn{7}{l}{ Total } & & & &
\end{tabular}

Tabel 20 menunjukkan bahwa jumlah responden yang paling banyak menjawab mengenai harga jual sayuran terhadap Peningkatanharga produk organik berpendapat bahwa harga mahal adalah (setuju) 20 orang $(51,2 \%)$ dan yang menjawab (Tidak setuju) sebanyak 3 orang $(7,6 \%)$ serta responden berpendapat (Masih Ragu-ragu) sebanyak 6 orang (15, $3 \%$ ) dan yang mejawab (sangat setuju) sebanyak 10 orang $(25,6 \%)$. Dengan ini, total skor nilai yang diperoleh 154 dan interpretasi sebanyak 78,9\%. Dan nilai interpretasi tergolong baik.

\begin{tabular}{|c|c|c|c|c|}
\hline $\begin{array}{c}\text { Alternatif } \\
\text { Jawaban }\end{array}$ & $\begin{array}{l}\text { Alternatif } \\
\text { Skor }\end{array}$ & $\begin{array}{l}\text { Jumlah Responden } \\
\text { (Orang) }\end{array}$ & $\begin{array}{c}\text { Persentase } \\
\text { Responden }(\%)\end{array}$ & $\begin{array}{l}\text { Total } \\
\text { Skor }\end{array}$ \\
\hline Sangat Setuju & 5 & - & - & - \\
\hline Setuju & 4 & 5 & 12,8 & 20 \\
\hline Ragu-Ragu & 3 & 10 & 25,6 & 30 \\
\hline Tidak Setuju & 2 & 17 & 43,5 & 34 \\
\hline Sangat Tidak Setuju & 1 & 7 & 17,9 & 7 \\
\hline Total & & 39 & 100 & 91 \\
\hline
\end{tabular}

Tabel 21 menunjukkan bahwa jumlah responden yang paling banyak menjawab mengenai kemudahan mencari pasar organik di Wilayah Kecamatann Tomohon Utara adalah (tidak setuju) 17 orang $(43,5 \%)$ dan yang menjawab (Ragu-ragu) sebanyak 10 orang $(25,6 \%)$ dan responden menganggap (sangat tidak setuju) sebanyak 7 orang $(17,9 \%)$ serta yang menjawab (setuju) sebanyak 5 orang $(12,8 \%)$. Dengan total skor yang peroleh 91 dan interpretasi sebanyak 46,6\%. Dan nilai tergolong kurang baik. 


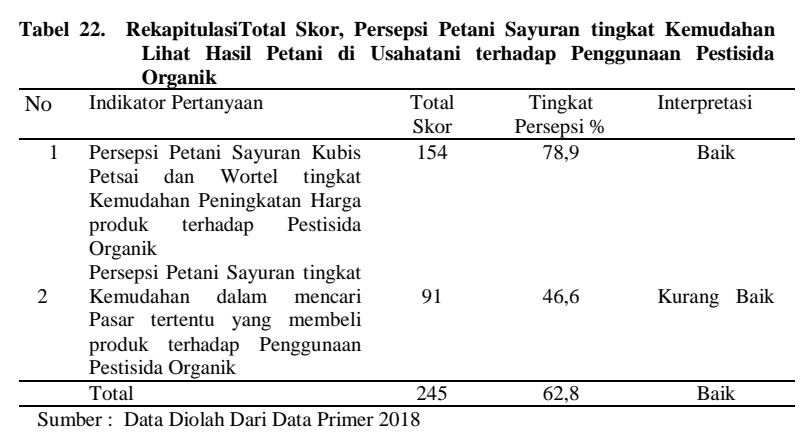

Tabel 22 menunjukkan bahwa dari keseluruhan indikator tingkat Kemudahan Dilihat Hasil Petani diusahatani terhadap Penggunaan Pestisida Organik adalah terletak pada skor sebesar 254 dan persentase tingkat persepsi petani sayuran sebesar 78,9\%. Artinya responden berpendapat tingkat harga produk terhadap pestisida organik yaitu Baik. dan indikator yang memperoleh persentasi tingktat kemudahan mencari pasar tertentu adalah 46,6\%. Artinya surit untuk mencari pasar tertentu yang membeli produk terhadap Penggunaan Pestisida Organik. Hal ini menujukkan bahwa nilai interpretasinya Kurang baik.

Rekapitulasi Hasil Pengambilan Data Tingkat Persepsi Petani Sayuran Kubis, Petsai Dan Wortel Terhadap Pestisida Organik Di Kelurahan Kakaskasen III Kecamatan Tomohon Utara Kota Tomohon.

Jumlah skor ideal untuk keseluruhan pertanyaan $=1950$ (Sangat Setuju) jumlah skor rendah $=390$ (Sangat Tidak Setuju). Berdasarkan data yang dihimpun dari 10 pertanyaan yang diajukan kepada 39 responden, maka diperoleh total skor 1153 dengan indeks tanggapan persepsi petani sayuran kubis, petsai dan wortel sebagai berikut:

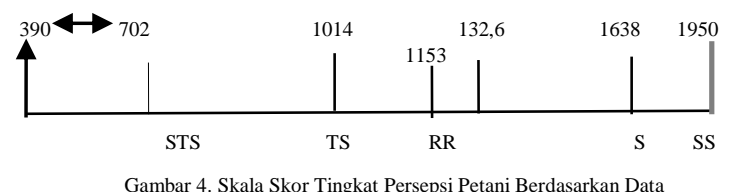

Secara persentase, indeks tingkat persepsi petani sayuran terletak pada:

Dengan indeks Tingkat Persepsi petani yaitu:

$$
\text { Tingkat Persepsi Petani }=\frac{1153}{1950} \times 100 \%=59,1 \%
$$

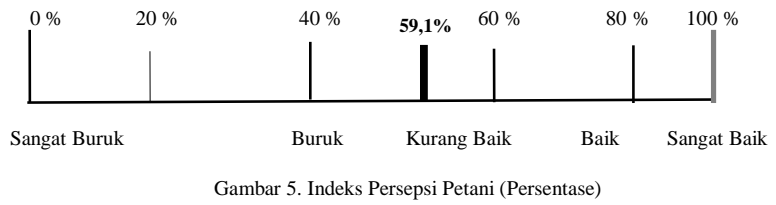

Berdasarkan hasil analisis menggunakan skala likert, maka dapat diketahui bahwa indeks tingkat persepsi petani sayuran kubis, petsai dan wortel di Kelurahan Kakaskasen III mengenai pestisida organik adalah berada pada $59,1 \%$ dan tergolong dalam kategori kurang baik.

\section{KESIMPULAN DAN SARAN}

\section{Kesimpulan}

Berdasarkan hasil analisis menggunakan skala likert, maka dapat disimpulkan bahwa total skor tingkat persepsi petani sayuran kubis, petsai dan wortel terhadap pestisida organik di Kelurahan Kakaskasen III, mengenai pestisida organik berjumlah 1.153, berada pada kategori tingkat persepsi ragu-ragu dengann nilai persentase sebesar 59,1\% sehingga dikategorikan kurang baik.

\section{Saran}

Secara umum persepsi petani sayuran kubis, wortel, dan petsai terhadap pestsida organik kurang baik. Sehingga untuk dapat memperoleh hasil yang lebih maksimal lagi maka perlu adanya perhatian dari pemerintahseperti halnya dilakukan dengan sosialisasi dan pemberian ketrampilan dalam pembuatan pestisida organik agar petani semangat dan mudah menghasilkan produk pestisida organik serta dapat menggunakan dalamu sahataninya, jika mendapatkan harga jualnya sayuran organik yang cukup tinggi dan dapat meningkatkan pendapatan petani, khususnya petani Kelurahan Kakaskasen III Kecamatan Tomohon Utara Kota Tomhon.

\section{DAFTAR PUSTAKA}

Anonim. 2012. T.M., Populasi dan Sampel Penelitian 4:Ukuran Sampel Rumus Slovin.http:// tatmaguny.wordpress.com/2018/ukuran-sampel rumus slovin.

Azwar. 2010, Analisis Menggunakan Skala Likert.

Bappenas. 2013. Perkembangan Dan Kemajuan Ekonomi Indonesia PT. Gramedia. Jakarta.

Hasiduwito, Sukamto. 2007. Langka-Langkah Membuat Pestisida Nabati Penerbit Agromedia Pustaka. Jakarta.

Nahar. 2010. Metode Penggunaan Pestisida Organik Secara Sistematis.

Nazaruddin. 2003. Perkembangan Pertanian Organik Di Indonesia Dimulai Pada Awal 1980-An.

Riduwan. 2008. Skala Pengukuran Variabel-Variabel Penelitian CV Alfabet.

Soenandar, M., \& Tcahjono, H. 2012, Sektor Pertanian dalam Perubahan Jumlah Penduduk, Jakarta Selatan PT. Agromedia Pustaka, Hal. 5-6. 